\title{
The 2DG-Neutral Red Test for Completeness of Vagotomy
}

\author{
THOMAS R. WEBER, M.D., THOMAS A. MILLER, M.D., \\ AND S. MARTIN LINDENAUER, M.D. \\ Department of Surgery, University of Michigan and Veterans Administration Hospital, \\ Ann Arbor, Michigan 48105
}

Submitted for publication November 8, 1974

Ever since vagotomy became an important part of modern peptic ulcer surgery, investigators have searched for a test that would reliably indicate the completeness of vagus nerve section. The insulin hypoglycemia test, originally advocated by Hollander [8], has remained the most widely utilized test for the completeness of vagotomy, but despite several modifications it's reliability has been questioned in a number of reports $[6,13,14]$. In addition, the Hollander test has only postoperative application and cannot be used intraoperatively.

Two-deoxy-D-glucose (2DG) is a potent vagal stimulant, causing an increase in gastric acid secretion greater than that produced by insulin-induced hypoglycemia [4]. The remarkable safety and low incidence of side effects associated with 2DG have been fully investigated in other studies involving humans $[4,9,12]$.

Neutral red is an azine dye that is secreted by the gastric parietal cells into the stomach lumen [1], but only in the presence of intact vagal innervation to the stomach [10]. Neutral red has likewise been shown to be safe for human use [7].

The present study is an attempt to use 2DG and neutral red in combination as a test for completeness of vagotomy both intraoperatively and postoperatively.

\section{METHODS}

\section{Patient Selection}

Eighteen males, ranging in age from 44 to $78 \mathrm{yr}$, who were patients at the Veterans Administration Hospital, Ann Arbor, MI, were studied. Six of the patients (Group I) had chronic peptic ulcer disease, proved by upper gastrointestinal radiography or gastroscopy, and were scheduled to undergo vagotomy and pyloroplasty.

The remaining 12 patients (Group II) experienced symptoms suggestive of recurrent peptic ulcer, at intervals ranging from 6 mo to $5 \mathrm{yr}$ after operation for peptic ulcer disease.

The operations that had been performed in Group II patients included vagotomy in all 12 , pyloroplasty in 10 , and antrectomy in two.

Because of the investigative nature of the study, patients with concomitant serious diseases, such as diabetes, active heart disease requiring medication, or hepatic or renal disease were not studied.

Laboratory studies performed both before and after the 2DG neutral red test included determinations of serum bilirubin, alkaline phosphatase, glutamic oxalotransaminase, total protein, albumin, sodium, potassium, chloride, $\mathrm{CO}_{2}$-combining power, and prothrombin time. Twelve-lead electrocardiogram was performed both before and after the 2DG-neutral red test, and a cardiac monitor was utilized during the test.

\section{Insulin Test}

All 18 patients underwent a Hollander test, using regular insulin, $0.2 \mathrm{u} / \mathrm{kg}$ body weight, intravenously to decrease serum glucose below $50 \mathrm{mg} / 100 \mathrm{ml}$. A positive response by Hollander's criteria [1] was indicated by an increase in free acid concentration of $20 \mathrm{meq}$ per liter over preinsulin levels in two successive 15-min aliquots. An 
increase of 10 meq per liter was accepted as positive if there was no free acid before the insulin injection.

Patients who underwent vagotomy after the initial insulin test were again studied with the insulin test 10 days postoperatively. This included the six patients in Group I and five patients in Group II. Four patients from Group I and three patients from Group II underwent a third Hollander test at least 3 mo postoperatively.

\section{DG-Neutral Red Test}

All 18 patients underwent the 2DG-neutral red test in the following manner: after an overnight fast, a nasogastric tube was placed and connected to suction, and an intravenous infusion of normal saline begun.

Aliquots of gastric secretion were collected at $15-\mathrm{min}$ intervals, and analyzed for acid in a manner identical to the Hollander test. Serum glucose levels were determined every $30 \mathrm{~min}$. After a baseline collection of gastric secretion, 2DG, $50 \mathrm{mg}$ per $\mathrm{kg}$ body weight, was given slowly intravenously. Ten minutes later neutral red, $50 \mathrm{mg}$, was given intravenously.

Any change in color of the gastric aspirate was noted over the next $90 \mathrm{~min}$.

Patients who underwent vagotomy were studied intraoperatively in the following manner: after vagotomy was completed, $2 \mathrm{DG}$ and neutral red were given in the same doses as the preoperative test. The presence of neutral red in the stomach was determined by swabbing the mucosa with a sponge through the gastroduodenotomy performed as a part of pyloroplasty.

These same patients were studied with the 2DG-neutral red test 10 days postoperatively. In addition, four patients from Group I and three patients from Group II underwent the 2DG-neutral red test at least 3 mo postoperatively.

\section{RESULTS}

The effects of the 2DG-neutral red test on the serum chemistries and electrocardiographs of the 18 patients studied are sum-
TABLE 1

Mean Values of Liver Function Tests and Blood Chemistries Among 18 Patients Undergoing 2DG-Neutral Red Tests

\begin{tabular}{lll}
\hline & \multicolumn{1}{c}{$\begin{array}{c}\text { Before } \\
\text { 2DG-NR test }\end{array}$} & \multicolumn{1}{c}{$\begin{array}{c}\text { After } \\
\text { 2DG-NR test }\end{array}$} \\
\hline $\begin{array}{l}\text { Bilirubin } \\
\text { Alkaline } \\
\text { phosphatase }\end{array}$ & $0.4 \mathrm{mg} / 100 \mathrm{ml}$ & $0.6 \mathrm{mg} / 100 \mathrm{ml}$ \\
$\begin{array}{l}\text { Glutamic } \\
\text { oxalotransaminase }\end{array}$ & $290 \mathrm{u}$ & $175 \mathrm{u}$ \\
$\begin{array}{l}\text { Total protein } \\
\text { Albumin }\end{array}$ & $6.8 \mathrm{~g} / 100 \mathrm{ml}$ & $7.2 \mathrm{~g} / 100 \mathrm{ml}$ \\
$\begin{array}{l}\text { Prothrombin } \\
\text { concentration }\end{array}$ & $3.94 \mathrm{~g} / 100 \mathrm{ml}$ & $3.74 \mathrm{~g} / 100 \mathrm{ml}$ \\
Sodium & $95 \%$ & \\
$\begin{array}{l}\text { Potassium } \\
\text { Chloride }\end{array}$ & $141.6 \mathrm{meq} / \mathrm{liter}$ & $137.8 \mathrm{meq} / \mathrm{liter}$ \\
CO 2 & $4.4 \mathrm{meq} / \mathrm{liter}$ & $4.5 \mathrm{meq} / \mathrm{liter}$ \\
ECG & $100.5 \mathrm{meq} / \mathrm{liter}$ & $99.8 \mathrm{meq} / \mathrm{liter}$ \\
& $25.2 \mathrm{meq} / \mathrm{liter}$ & $25.9 \mathrm{meq} / \mathrm{liter}$ \\
& No changes & No changes \\
\hline
\end{tabular}

marized in Table 1. There were no significant changes in either liver function, serum electrolytes, or electrocardiograph attributable to the 2DG-neutral red test.

The blood sugar levels in response to 2DG and insulin are shown in Fig. 1. Insulin caused an abrupt fall in blood glucose level within $30 \mathrm{~min}$ to below $50 \mathrm{mg} / 100 \mathrm{ml}$, which gradually increased to $70 \mathrm{mg} / 100 \mathrm{ml}$ at 120 min postinjection. In contrast, 2DG caused a mild hyperglycemia, eventually increasing to $135 \mathrm{mg} / 100 \mathrm{ml}$ at $90 \mathrm{~min}$, at which time the glucose level began to fall.

Table 2 shows the basal and stimulated free acid levels preoperatively and post-

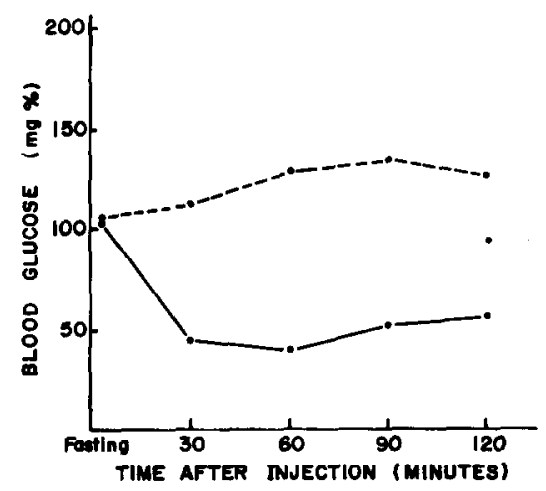

FIG. 1. Mean blood glucose values in response to 2DG (--) and insulin (- - ) (18 patients). 
TABLE 2

Mean Values of Free Acid in Milliequivalents per Liter Among 18 Patients Undergoing 2DG-Neutral Red and Insulin Tests

\begin{tabular}{|c|c|c|c|c|c|}
\hline & & Basal & $15 \mathrm{mir}$ & $30 \mathrm{~min}$ & $45 \mathrm{~min}$ \\
\hline \multirow[t]{2}{*}{ Preopera tive } & 2DG-NR & 28.0 & 58.0 & 86.8 & 98.6 \\
\hline & Insulin & 22.3 & 46.0 & 67.0 & 67.0 \\
\hline \multirow[t]{2}{*}{ Postoperative } & 2DG-NR & 3.0 & 4.8 & 6.2 & 7.7 \\
\hline & Insulin & 2.0 & 4.3 & 6.7 & 5.5 \\
\hline
\end{tabular}

operatively in response to the 2DG-neutral red test and the insulin test. $2 \mathrm{DG}$ proved to be a stronger stimulant to acid secretion than insulin, both pre- and postoperatively. However, the differences were not statistically significant.

The results of the preoperative, intraoperative, and postoperative 2DG-neutral red tests and insulin tests for the six patients in Group I (no previous peptic ulcer surgery) are summarized in Table 3. For these and all subsequent pre- and postoperative 2DG-neutral red tests, the appearance of red or purple dye in the nasogastric tube aspirate within $30 \mathrm{~min}$ after the intravenous injection of neutral red was considered a positive test (vagus nerves intact). In the intraoperative test, appearance of purple dye on the swabbing sponge within $30 \mathrm{~min}$ after the injection of neutral red was likewise considered positive. All six patients in Group I had a prompt appearance of neutral red in the nasogastric aspirate when tested preoperatively, while only five of six patients had a positive Hollander test before operation.

The 2DG-neutral red tests performed intraoperatively and 10 days postoperatively were negative, as were the insulin tests

TABLE 3

Results of 2DG-Neutral Red and Insulin Tests Among Six Patients in Group I

\begin{tabular}{llc}
\hline & & No. positive tests \\
\hline Preoperative & 2DG-NR & $6 / 6$ \\
& Insulin & $5 / 6$ \\
Intraoperative & 2DG-NR & $0 / 6$ \\
Postoperative 10 days & 2DG-NR & $0 / 6$ \\
& Insulin & $0 / 6$ \\
Postoperative 3 mo & 2DG-NR & $0 / 4$ \\
& Insulin & $1 / 4$ \\
\hline
\end{tabular}

TABLE 4

Results of Preoperative 2DG-Neutral Red and Insulin Tests Among 12 Patients in Group II

\begin{tabular}{rc}
$\begin{array}{c}\text { Negative 2DG-NR } \\
\text { negative insulin } \\
\text { Positive 2DG-NR } \\
\text { positive insulin }\end{array}$ & $7 / 12$ \\
$\begin{array}{r}\text { Positive 2DG-NR } \\
\text { negative insulin }\end{array}$ & $2 / 12$ \\
\hline
\end{tabular}

performed 10 days postoperatively. Four of the six patients were studied 3 mo postoperatively, with one positive insulin test and no positive 2DG-neutral red tests noted. None of the four patients evaluated $3 \mathrm{mo}$ postoperatively had symptoms suggestive of recurrent peptic ulcer disease.

The results of the preoperative 2DG-neutral red and insulin tests in the 12 patients in Group II (possible recurrent ulcer after surgery) are summarized in Table 4 . The patients could be classified into three groups. Seven of the 12 patients had negative 2DGneutral red and insulin tests, and did not undergo operation. Three of the 12 patients had positive 2DG-neutral red tests and positive insulin tests, and subsequently were operated upon. The final two patients had positive 2DG-neutral red tests, but negative insulin tests and were also operated upon. It should be noted that each of the five patients that underwent operation had recurrent peptic ulcer disease seen on either upper gastrointestinal radiography or gastroscopy. Each patient was found at operation to have one or more intact vagus nerves and evidence of recurrent ulcer disease.

The results of the intraoperative and

TABLE 5

Results of 2DG-Neutral Red and Insulin Tests

Among Five Patients with Recurrent Peptic Ulcer Undergoing a Second Operation

\begin{tabular}{llc}
\hline & & No. positive tests \\
\hline Intraoperative & 2DG-NR & $0 / 5$ \\
Postoperative 10 days & 2DG-NR & $0 / 5$ \\
& Insulin & $0 / 5$ \\
Postoperative 3 mo & 2DG-NR & $0 / 3$ \\
& Insulin & $0 / 3$ \\
\hline
\end{tabular}


postoperative 2DG-neutral red tests and postoperative insulin tests performed on the five patients from Group II that underwent operation are detailed in Table 5. The 2DGneutral red test was negative both intraoperatively and 10 days postoperatively, as was the insulin test performed 10 days postoperatively. Three patients were studied 3 mo postoperatively, with both tests negative in each patient. None of the patients evaluated 3 mo postoperatively experienced symptoms of recurrent ulcer disease.

\section{DISCUSSION}

Since its introduction by Hollander [8], the insulin hypoglycemia test of vagal function has enjoyed great popularity despite many well-known drawbacks. It seems to be a very reliable test when the acid increase is 20 meq per liter or greater in a $15-$ min period, but many times a smaller increase in acid output only serves to confuse the clinician trying to decide if vagal function is present and further operative intervention is indicated. There is an obvious need for a test for the completeness of vagotomy that gives more consistently an "all or none" result, with less question as to whether it is positive or negative. In addition, the optimal time to test for completeness of vagal section is at the time of operation, thus reducing the chances that further surgery might be necessary.

Two deoxy-D-glucose (2DG) has been shown to be a potent vagal stimulant [4]. Its mechanism of action is apparently through the production of hypothalamic glucocytopenia, which in turn stimulates the dorsal motor nucleus of the vagus [3]. The response to 2DG is abolished by vagotomy [5].

Neutral red is a weakly basic azine dye that has been shown by numerous investigators to be secreted selectively by the gastric parietal cells $[1,7,10,11]$. The gastric juice turns a pink, then purple color within 3-5 min after the intravenous injection of neutral red in the presence of vagal stimulation. In contrast, neutral red will not appear in the gastric juice if the vagal innervation to the stomach has been interrupted [10].

Cole [2] suggested that 2DG and neutral red might be combined in an intraoperative test for completeness of vagotomy, and proved its value in studies in dogs. However, there have been few studies in humans with the 2DG-neutral red combination.

The present study clearly demonstrates the value of the $2 \mathrm{DG}$-neutral red test as a postoperative test for completeness of vagotomy. In addition, the $2 \mathrm{DG}$-neutral red test in this study proved superior to the Hollander test, as one patient with a strongly positive neutral red test, but a negative Hollander test was found at operation to have an intact vagus nerve. Postoperatively his neutral red test became negative. In addition, a patient in Group I who had never had a vagotomy had a negative Hollander test.

The ultimate value of the intraoperative 2DG-neutral red test needs further evaluation. The fact that there was an exact correlation between negative intraoperative and postoperative 2DG-neutral red tests is only presumptive evidence that the intraoperative test is useful. Unpublished data from studies performed in our laboratory have shown that in the dog both intramuscular atropine given preoperatively and vigorous traction on intact vagus nerves will give negative intraoperative and postoperative 2DG-neutral red tests. These factors must be considered when evaluating the intraoperative 2DGneutral red test or any other intraoperative test for the completeness of vagal section. Studies are currently underway to evaluate further these factors.

\section{REFERENCES}

1. Bradford, N., and Davis, R. The site of hydrochloric acid production in the stomach as determined by indicators. Biochem. J. 46:414, 1950.

2. Cole, R. An intraoperative test for the completeness of vagotomy. Am. J. Surg. 123:543, 1972.

3. Collin-Jones, D., and Himsworth, R. The location of the chemoreceptor controlling gastric acid secretion during hypoglycemia. J. Physiol. 206:397, 1970. 
4. Duke, W., Hirschowitz, B., and Sachs, G.: Vagal stimulation of gastric secretion in man by 2-deoxyD-glucose. Lancet 2:871, 1965.

5. Eisenberg, M., Emas, G., and Grossman, M. Comparison of the effect of 2-deoxy-D-glucose and insulin on gastric acid secretion in dogs. Surgery 60:111, 1966.

6. Gillespie, G., Elder, J., Gillespie, I., Kay, A., and Campbell, E. The long term stability of the insulin test. Gastroenterology 58:625, 1970.

7. Gillman, T. A critical evaluation of the neutral red excretion and acid secretion lests of gastric function in the normal and in subjects with gastric disorders. Gastroenterology 3:188, 1944.

8. Hollander, F. Laboratory procedures in the study of vagotomy. Gastroenterology 11:419, 1948.

9. Laszlo, J., Harlan, W., and Klein, R. F. The effect of 2-deoxy-D-glucose infusions on lipid and carbohydrate metabolism in man. J. Clin. Invest. 40:171, 1961 .

10. Morrison, S., Gardner, R., and Reeves, D. The selective elimination of neutral red through the gastric mucosa. J. Lab. Clin. Med. 21:822, 1936.

11. Piersol, G., Bockus, H., and Bank, J. The practical value of neutral red as a test for gastric secretory function. Am.J. Med.Sci. 170:405, 1925.

12. Stalder, G., Schultheiss, H., and Allgower, M. Use of 2-deoxy-D-glucose for testing completeness of vagotomy in man. Gastroenterology 63:552, 1972.

13. Watkin, D. The delayed insulin test and recurrent duodenal ulceration. Br. J. Surg. 58:775, 1971.

14. Watkin, D., and Duthie, H. Changes in the postoperative insulin test in relation to recurrent duodenal ulceration. Gut 12:303, 1971. 